\title{
Inflammasome Proteins As Biomarkers of Multiple Sclerosis
}

\author{
Robert W. Keane ${ }^{1,2}$, W. Dalton Dietrich ${ }^{2,3}$ and Juan Pablo de Rivero Vaccari ${ }^{2,3 *}$ \\ ${ }^{1}$ Department of Physiology and Biophysics, Miller School of Medicine, University of Miami, Miami, FL, United States, \\ 2 InflamaCORE, LLC, Miami, FL, United States, ${ }^{3}$ Department of Neurological Surgery, The Miami Project to Cure \\ Paralysis, Miller School of Medicine, University of Miami, Miami, FL, United States
}

OPEN ACCESS

Edited by:

Thomas G. Forsthuber, University of Texas at San Antonio, United States

Reviewed by: Charlotte Elisabeth Teunissen, VU University Amsterdam, Netherlands Vincent Van Pesch, Université Catholique de Louvain, Belgium

*Correspondence:

Juan Pablo de Rivero Vaccari jderivero@med.miami.edu

Specialty section: This article was submitted to

Multiple Sclerosis and Neuroimmunology, a section of the journal Frontiers in Neurology

Received: 16 November 2017 Accepted: 23 February 2018 Published: 19 March 2018

Citation: Keane RW, Dietrich WD and de Rivero Vaccari JP (2018) Inflammasome Proteins As Biomarkers of Multiple Sclerosis. Front. Neurol. 9:135. doi: 10.3389/fneur.2018.00135
Multiple sclerosis (MS) is an autoimmune disease that affects the brain and spinal cord. The inflammasome is a multiprotein complex that contributes to the innate immune response in animal models of MS as well as in patients with the disease. Important to the care of patients with MS is the need for biomarkers that can predict disease onset, disease exacerbation, as well as response to treatment. In this study, we analyzed serum samples from 32 patients with MS and 120 age-matched controls, and provide receiver operator characteristic (ROC) curves with associated confidence intervals following analyses of serum samples from patients with MS, most of which had the relapsing-remitting form of the disease, and from healthy unaffected donors, and determine the sensitivity and specificity of inflammasome proteins as biomarkers of MS. We report that caspase-1 (1.662 \pm 0.6024 difference between means), apoptosis-associated speck-like protein containing a caspase recruitment domain (ASC) (407.5 \pm 35.79$)$, and interleukin (IL)-18 $(78.53+17.86)$ were elevated in the serum of MS patients when compared to controls. Interestingly, the levels of IL-1 $\beta(-0.5961 \pm 0.265)$ were lower in the MS cohort. Importantly, the area under the curve (AUC) for ASC and caspase- 1 were 0.9448 and 0.848 , respectively. Taken together, these data suggest that ASC and caspase- 1 could be potential candidate biomarkers for MS onset.

Keywords: inflammasome, biomarkers, serum, caspase-1, apoptosis-associated speck-like protein containing a caspase recruitment domain, multiple sclerosis

\section{INTRODUCTION}

Multiple sclerosis (MS) is a progressive autoimmune disorder that affects the central nervous system (CNS). Pathologically, it is characterized by demyelination in the spinal cord and brain as well as the presence of inflammatory lesions (1). The current belief is that MS is an autoimmune disease characterized by autoreactive $\mathrm{T}$ lymphocytes that originate in the peripheral immune system and migrate to the CNS (2). Clinically, patients with MS present blurred vision, muscle weakness, fatigue, dizziness, as well as balance, and gait problems (1). Importantly, current therapies for MS target the inflammatory response, thus highlighting the relevance of further investigation on the immune response in MS (3-5).

In the United States, alone, there are 400,000 patients with MS and about 2 million patients worldwide (1). An important area of research in the field of MS is the identification of suitable biomarkers to predict who is at risk of developing MS, biomarkers of disease progression or exacerbation, as well as biomarkers of treatment response and prognosis (1).

The inflammasome is a key mediator of the innate immune response that in the CNS was first described to mediate inflammation after spinal cord injury (6). The inflammasome is a multiprotein complex involved in the activation of caspase- 1 and the processing of the pro-inflammatory 
cytokines, interleukin (IL)-1 $\beta$ and IL-18 (7). The inflammasome contributes to the inflammatory response in MS. For instance, caspase- 1 and IL- 1 are present in MS plaques, and these proteins are also elevated in peripheral blood mononuclear cells of MS patients $(8,9)$. In addition, the NOD-like receptor protein-3 (NLRP3) inflammasome has been shown to play a role in the development of experimental autoimmune encephalomyelitis (EAE) in mice. Accordingly, mice deficient in NLRP3 were protected from developing EAE, while apoptosis-associated speck-like protein containing a caspase recruitment domain (ASC) and caspase-1-deficient mice also contributed to the disease (10-12).

In this study, we provide receiver operator characteristic (ROC) curves with associated confidence intervals following analyses of serum samples from patients with MS and from healthy unaffected donors. In addition, we determine the sensitivity and specificity of inflammasome proteins to examine the potential of inflammasome signaling proteins as biomarkers of MS.

\section{MATERIALS AND METHODS}

\section{Participants}

Subjects were enrolled in the study Prospective Collection of Samples for Research according to IRB \# 201301461 approved by Schulman Associates IRB for BioreclamationIVT. In this study, we analyzed serum samples from 120 normal donors and 32 patients who were diagnosed with MS. Samples were purchased from BioreclamationIVT. The normal donor group consisted of samples obtained from 60 male and 60 female donors in the age range of 20-70 years old. These patients had no clinical diagnosis of MS or any other disease at the time of blood donation. The age range in the MS group consisted of samples obtained from patients in the age range of 24-64 years old. As shown in Table 1, 20 patients were being treated with Tysabri, 20 were diagnosed with mild to moderate relapsing remitting MS (RRMS), 2 with secondary progressive MS (SPMS) (moderate), and 10 were unspecified. Three patients were treated with Tecfidera, one with Copaxone, two with Gilenya, one with Rebif, one with Betaseron, one with Ampyra, and three untreated with a medication for MS.

\section{Simple Plex Assay}

Concentration of inflammasome proteins caspase-1, ASC, IL-1 $\beta$, and IL-18 in serum was analyzed as described in Ref. (13) using the Ella System (Protein System). The Simple Plex assay was analyzed by the Simple Plex Explorer software. Results shown correspond to the mean of each sample run in triplicates. The limit of quantitation for ASC was $13.1 \mathrm{pg} / \mathrm{ml}$ (lower limit of quantitation, LLOQ) and $8,000 \mathrm{pg} / \mathrm{ml}$ (upper limit of quantitation), for caspase- $1,0.66-1,000 \mathrm{pg} / \mathrm{ml}$, for IL- $1 \beta, 0.21-840 \mathrm{pg} / \mathrm{ml}$, and for IL-18, $0.390-3,660 \mathrm{pg} / \mathrm{ml}$. The intra-assay mean for ASC was $47 \pm 2.8 \mathrm{pg} / \mathrm{ml}$ (low QC $\pm \mathrm{SD}$ ) and 2,806 $\pm 152 \mathrm{pg} / \mathrm{ml}$ (high $\mathrm{QC} \pm \mathrm{SD}$ ), for caspase-1, $5.3 \pm 0.266$ and $266 \pm 17.8 \mathrm{pg} / \mathrm{ml}$, for IL-1 $\beta, 8.66 \pm 0.427$ and $446 \pm 16.5 \mathrm{pg} / \mathrm{ml}$, and for IL-18,10.5 \pm 0.524 and $569 \pm 18.7 \mathrm{pg} / \mathrm{ml}$. The inter-assay mean for ASC was $51.1 \pm 5.5$ and 2,551 $\pm 257 \mathrm{pg} / \mathrm{ml}$, for caspase- 1 ,
$5.81 \pm 0.816$ and $269 \pm 29 \mathrm{pg} / \mathrm{ml}$, for IL- $1 \beta, 8.42 \pm 0.342$ and $410 \pm 23.3 \mathrm{pg} / \mathrm{ml}$, and for IL-18, $10.3 \pm 0.882$ and $587 \pm 58.4 \mathrm{pg} / \mathrm{ml}$.

\section{Biomarker Analyses}

Prism 7 software (GraphPad) was used to analyze the data obtained from the Simple Plex Explorer Software. Comparisons between groups were carried after identifying outliers followed by determination of the area under the ROC curve, as well as the $95 \%$ confidence interval (CI). The $p$-value of significance used was $<0.05$. Sensitivity and specificity of each biomarker was obtained for a range of different cut-off points. Samples that yielded a protein value below the level of detection of the assay were not included in the analyses for that particular analyte.

\section{RESULTS}

\section{Caspase-1, ASC, and IL-18 Are Elevated in the Serum of MS Patients}

We analyzed serum samples from MS patients and compared them to serum from healthy/control individuals using a Simple Plex assay (Protein Simple) for the protein expression of the inflammasome signaling proteins caspase-1, ASC, IL-1 $\beta$, and IL-18 (Figure 1). Accordingly, we found that the protein levels of caspase-1, ASC, and IL-18 in the serum of MS patients was higher than in the control group. However, the levels of IL-1 $\beta$ were lower in the MS than controls. These findings are consistent with previous reports indicating a role for the inflammasome in the pathology of MS $(10,11,14)$.

\section{ASC and Caspase-1 Are Promising Serum Biomarkers of MS}

To then determine if these inflammasome signaling proteins have the potential to be reliable biomarkers for MS pathology, we determined the area under the curve (AUC) for caspase-1 (Figure 2A), ASC (Figure 2B), IL-1 $\beta$ (Figure 2C), and IL-18 (Figure 2D). Of the proteins that we measured, ASC was shown to be the best potential biomarker (Figure 3) with an AUC of 0.9448 and a CI between 0.9032 and 0.9864 (Table 2). In addition, caspase- 1 with an AUC of 0.848 and a CI between 0.703 and 0.9929 is also promising biomarker of MS.

Furthermore, the cut-off point for ASC was $352.4 \mathrm{pg} / \mathrm{ml}$ with $84 \%$ sensitivity and $90 \%$ specificity (Table 2). For caspase-1, the cut-off point was $1.302 \mathrm{pg} / \mathrm{ml}$ with $89 \%$ sensitivity and $56 \%$ specificity (Table 2). Moreover, we found that with regards to ASC for a $100 \%$ sensitivity, the cut-off point was $247.2 \mathrm{pg} / \mathrm{ml}$ with $58.26 \%$ specificity, and for $100 \%$ specificity, the cut-off point was $465.1 \mathrm{pg} / \mathrm{ml}$ with $65.63 \%$ sensitivity. In the case of caspase- 1 , for $100 \%$ sensitivity, the cut-off point was $1.111 \mathrm{pg} / \mathrm{ml}$ with $44.44 \%$ specificity. For $100 \%$ specificity, the cut-off point was $2.718 \mathrm{pg} / \mathrm{ml}$ with $52.63 \%$ sensitivity. Thus, these findings indicate that caspase- 1 and ASC are promising biomarkers for MS.

\section{ASC Is a Promising Biomarker of MS Severity in Serum}

We then separated the groups into mild and moderate MS. Accordingly, we found that the protein level of ASC was higher 
TABLE 1 | Subjects with multiple sclerosis (MS) gender.

\begin{tabular}{|c|c|c|c|c|c|c|}
\hline Gender & Age & Diagnosis & Medications & Race & Ethnicity & Condition \\
\hline Female & 46 & MS & $\begin{array}{l}\text { Tysabri } 300 \text { mg, Abilify } 5 \text { mg, Ditropan } 15 \text { mg, Effexor } \\
150 \text { mg, Feosol } 325 \text { mg, Ketoconazole, Klonopin } 2 \text { mg, } \\
\text { Topamax } 200 \text { mg, Wellibutrin } 300 \text { mg, Vicodin 7.5-750 mg }\end{array}$ & Caucasian & & RRMS-mild \\
\hline Male & 47 & MS, OA, asthma & $\begin{array}{l}\text { Tysabri } 300 \text { mg, Gabapentin } 800 \text { mg, Diazepam } 5 \text { mg, } \\
\text { Vitamin D } 50000 \text { iu }\end{array}$ & Caucasian & & RRMS-moderate \\
\hline Female & 48 & MS, osteoporosis, iron anemia & $\begin{array}{l}\text { Provigil } 200 \text { mg, Escitalopram } 20 \text { mg, Tysabri } 300 \text { mg, } \\
\text { Klonopin } 0.5 \text { mg, Fiorinal-Codeine 30-50 mg }\end{array}$ & Caucasian & & $\begin{array}{l}\text { Secondary } \\
\text { progressive MS } \\
\text { (SPMS)-moderate }\end{array}$ \\
\hline Male & 30 & MS & Tecfidera $240 \mathrm{mg}$ & Caucasian & $\begin{array}{l}\text { Native } \\
\text { American }\end{array}$ & RRMS-mild \\
\hline Female & 34 & MS & Tysabri 300 mg & Caucasian & & RRMS-Mild \\
\hline Female & 49 & MS, depression & $\begin{array}{l}\text { Adderall } 18 \text { mg, Amlodipine } 5 \text { mg, Detrol, Hydrochlorothiazide } \\
25 \text { mg, Wellbutrin } 300 \text { mg, Ocuvite, Rebif } 44 \text { mcg, Topamax } \\
50 \text { mg, Vitamin D3 }\end{array}$ & Caucasian & & RRMS-mild \\
\hline Female & 24 & $\begin{array}{l}\text { MS, hypercholesterolemia, } \\
\text { polycystic ovary syndrome (PCOS) }\end{array}$ & $\begin{array}{l}\text { Neurontin } 300 \text { mg, Percocet 5-325mg, Tizanidine } 2 \text { mg, } \\
\text { Tysabri } 300 \text { mg, Xanax } 0.5 \text { mg, Zoloft } 50 \text { mg }\end{array}$ & Caucasian & & RRMS-moderate \\
\hline Female & 62 & MS & $\begin{array}{l}\text { Tysabri, Baclofen, Ampyra, Vitamin D, Aspirin } 81 \text { mg, } \\
\text { Mutlivitamin, Cranberry, Statin }\end{array}$ & Caucasian & & RRMS-mild \\
\hline Male & 51 & $\begin{array}{l}\text { MS, hypoglycemia, } \\
\text { asthma (unspecified) }\end{array}$ & $\begin{array}{l}\text { Baclofen } 10 \text { mg, Ditropan } 15 \text { mg, Provigil } 200 \text { mg, } \\
\text { Wellbutrin } 150 \text { mg, Multivitamin, Tysabri } 300 \text { mg }\end{array}$ & Caucasian & & $\begin{array}{l}\text { MS-moderate } \\
\text { (Relapsing } \\
\text { Remitting) }\end{array}$ \\
\hline Female & 38 & Migraine, MS & $\begin{array}{l}\text { Synthroid } 375 \text { mg, Cytomel } 50 \text { mg, Vitamins, } \\
\text { Copaxone } 40 \text { mg }\end{array}$ & Caucasian & & \\
\hline Male & 32 & Migraine, MS & $\begin{array}{l}\text { Gilenya } 0.5 \text { mg, Baclofen } 20 \text { mg, Adderall } 10 \text { mg, Klonopin } \\
1 \text { mg, Lyrica } 75 \text { mg, Venlafaxine } 37.5 \text { mg, Cambia } 50 \text { mg }\end{array}$ & Unknown & & \\
\hline Female & 30 & Migraine, MS & $\begin{array}{l}\text { Tysabri } 300 \text { mg, Adderall } 20 \text { mg, Topamax } 50 \text { mg, } \\
\text { Ambien } 10 \text { mg }\end{array}$ & Caucasian & & \\
\hline Male & 36 & Migraine, hypercholesterolemia, MS & Tysabri, Wellbutrin 50 mg, Lipitor 20 mg, Vitamin D3 & Caucasian & & \\
\hline Female & 48 & MS, anxiety, depression, migraine & $\begin{array}{l}\text { Topamax } 25 \text { mg, Keflex } 250 \text { mg, Cephalosporin } \\
200 \text { mg, Linzess } 145 \mathrm{mcg} \text {, Lexapro } 10 \text { mg, Flexeril } \\
10 \text { mg, Gilenya } 0.5 \text { mg }\end{array}$ & Caucasian & & RRMS-mild \\
\hline Female & 55 & $\begin{array}{l}\text { Migraine, hypercholesterolemia, } \\
\text { MS, asthma }\end{array}$ & $\begin{array}{l}\text { Betaseron } 0.3 \mathrm{mg} \text {, Fluoxetine } 20 \mathrm{mg} \text {, Atorvastatin } 20 \mathrm{mg} \text {, } \\
\text { Multivitamin, Calcium, Vitamin D, Aspirin, Probiotic, Maxalt }\end{array}$ & Caucasian & & \\
\hline Female & 41 & $\begin{array}{l}\text { Migraine, asthma, } \\
\text { endometriosis, colitis, MS }\end{array}$ & $\begin{array}{l}\text { Topamax } 100 \text { mg, Trexamet, Amitriptyline } 25 \text { mg, Clarinex, } \\
\text { Zyrtec, Aspirin } 81 \text { mg }\end{array}$ & Caucasian & $\begin{array}{l}\text { Native } \\
\text { American }\end{array}$ & \\
\hline
\end{tabular}


TABLE 1 | Continued

\begin{tabular}{|c|c|c|c|c|c|c|}
\hline Gender & Age & Diagnosis & Medications & Race & Ethnicity & Condition \\
\hline Male & 37 & Migraine, MS, vertigo & Tysabri, Tyzanidine & Caucasian & & \\
\hline Female & 41 & MS & $\begin{array}{l}\text { Vitamin D 2,000 U, Trazodone } 50 \text { mg, Maxalt } 10 \text { mg, } \\
\text { Valacyclovir 1, Medrol } 4 \text { mg, Alaprazolam } 0.5 \text { mg, Lyrica } \\
50 \text { mg, Provigil } 200 \text { mg, Cymbalta } 60 \text { mg, Tysabri } 300 \text { mg }\end{array}$ & Caucasian & & RRMS-moderate \\
\hline Male & 43 & MS & Tysabri 300 mg & African & $\begin{array}{l}\text { African- } \\
\text { American }\end{array}$ & RRMS-mild \\
\hline Female & 47 & Migraines, MS, psoriasis, infertility & B12, Tysabri 300mg/15ml, Xanax 0.5 mg, Advil & Caucasian & & \\
\hline Female & 53 & Migraines, MS & $\begin{array}{l}\text { Tecfidera } 240 \text { mg, Ampyra } 10 \text { mg, Aranesp, Topamax } \\
100 \text { mg, Myrbetriq } 5 \text { mg, Linzess, Sumatriptan, Treximet } \\
85 \text { mg, Ritalin } 10 \text { mg }\end{array}$ & Caucasian & & \\
\hline Female & 54 & MS & $\begin{array}{l}\text { Bystolic } 2.5 \text { mg, Sertraline } 50 \text { mg, Toviaz } 4 \text { mg, } \\
\text { Tysabri } 300 \text { mg }\end{array}$ & Caucasian & & RRMS-moderate \\
\hline Female & 47 & MS & Ambien 10 mg, Clorazepate 7.5 mg, Zoloft 50 mg & Caucasian & & RRMS-mild \\
\hline Female & 52 & MS & $\begin{array}{l}\text { Tecfidera } 240 \text { mg, Percocet 10-325 mg, Xanax } 0.5 \text { mg, } \\
\text { Ambien } 12.5 \text { mg, Prevacid, Calcium 1,000 mg, Prolera, } \\
\text { Cran Tab }\end{array}$ & Caucasian & & RRMS-mild \\
\hline Female & 54 & MS & $\begin{array}{l}\text { Baclofen } 10 \text { mg, Sarella } 50 \text { mg, Ampyra } 10 \text { mg, Lipitor } \\
40 \text { mg, Crestor } 20 \text { mg, Vesicare } 10 \text { mg, Synthroid } 0.5 \text { mg }\end{array}$ & Caucasian & & SPMS-moderate \\
\hline
\end{tabular}

A

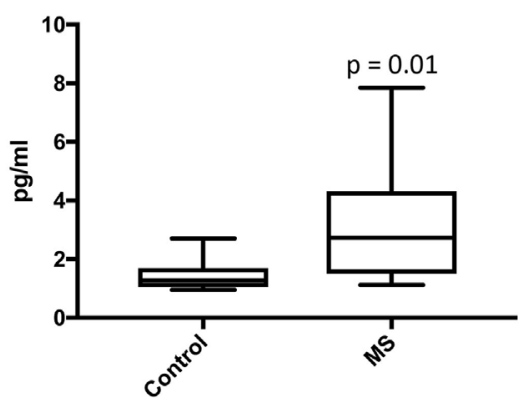

C

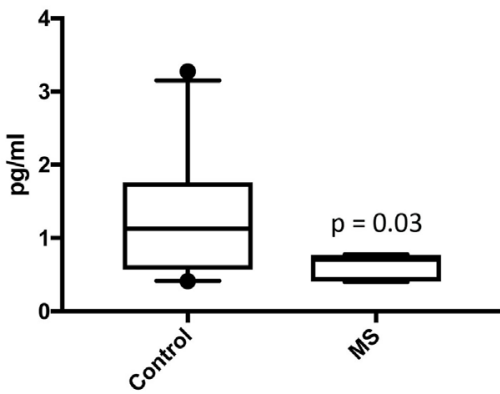

B

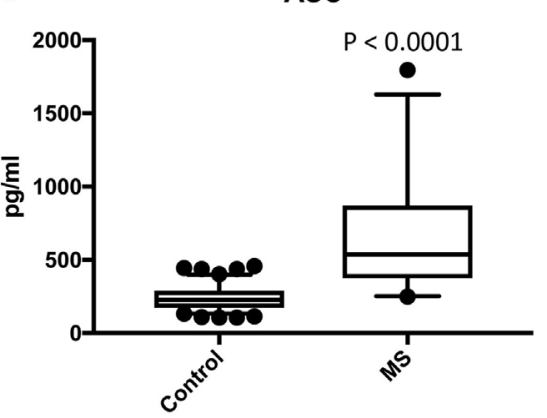

D

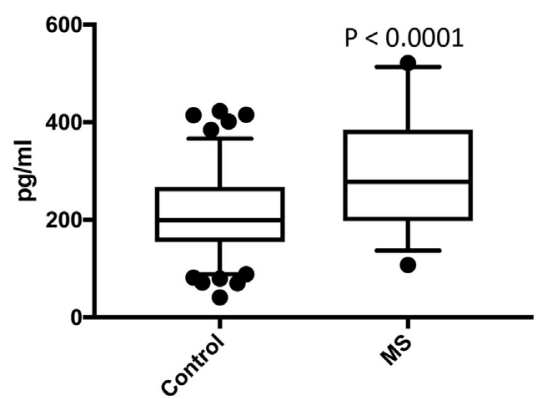

FIGURE 1 | Inflammasome proteins are elevated in the serum of MS patients. Protein levels in pg/ml of caspase-1 (A), apoptosis-associated speck-like protein containing a caspase recruitment domain (ASC) (B), IL-1 $\beta$ (C), and IL-18 (D) in serum samples from patients with MS and healthy donors. $p$-value of significance is shown above each box plot. Box and whiskers are shown for the 5th and 95th percentile. Caspase-1: $N=9$ control and 19 MS; ASC: $N=115$ control and 32 MS; IL-1 $\beta: N=21$ control and $8 \mathrm{MS}$; and IL-18: $N=119$ control and $32 \mathrm{MS}$.

in the serum of MS patients with moderate disease onset than in the mild group ( $p=0.044$ ) (Figure $4 B$ ), whereas the caspase-1 (Figure 4A) and IL-18 (Figure 4C) levels were not statistically different between the two groups. To then determine if inflammasome proteins can be used as diagnostic biomarkers of disease severity, we determined the AUC for caspase-1 (Figure 4D), ASC (Figure 4E), and IL-18 (Figure 4F). Of the proteins that we measured, ASC was shown to be the best biomarker with an AUC of 0.7596 and a CI between 0.5437 and 0.9756 (Table 3). Furthermore, the cut-off point for ASC was $537.5 \mathrm{pg} / \mathrm{ml}$ with 

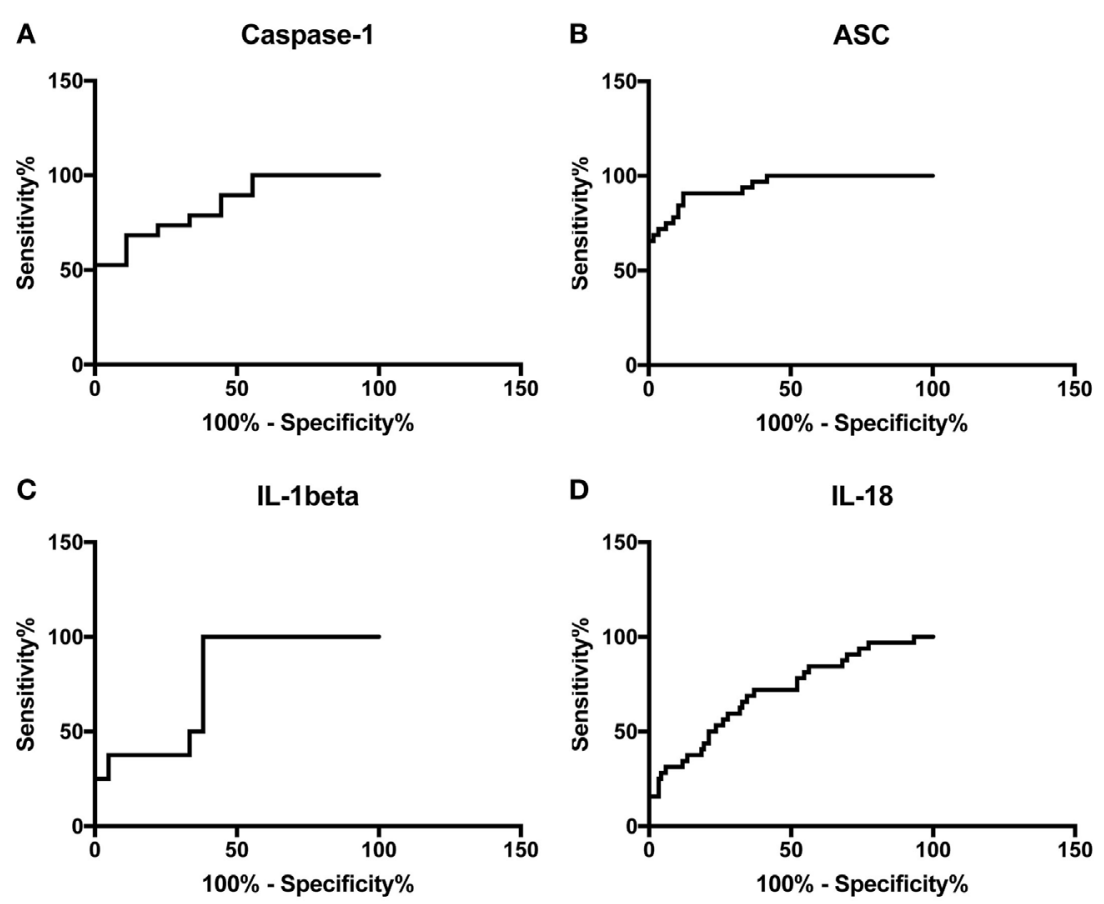

FIGURE 2 | Receiver operator characteristic curves for caspase-1 (A), apoptosis-associated speck-like protein containing a caspase recruitment domain (B), IL-1 $\beta$ (C), and IL-18 (D) from serum samples of multiple sclerosis and healthy donors.

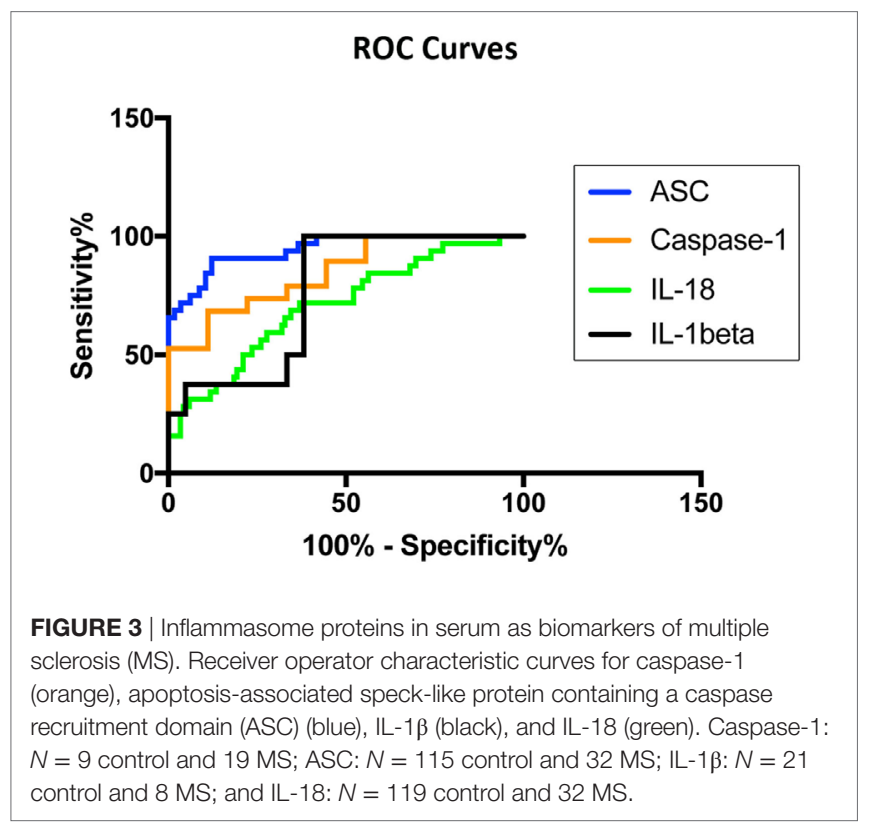

$75 \%$ sensitivity and $62 \%$ specificity (Table 3 ). Thus, these findings indicate that ASC is a promising diagnostic biomarker for MS severity.

\section{DISCUSSION}

Multiple sclerosis is an autoimmune disease that affects the brain and spinal cord characterized by the presence of inflammatory lesions and demyelination (1). In MS, T-cells originating in the peripheral immune response and eventually infiltrate the CNS, producing demyelination and axon degeneration (15). The source of autoimmunity in MS remains to be identified. However, anti-inflammatory therapies have been shown to be efficient in reducing disease relapse and disease progression (3-5). It is possible that in addition to infiltrating T-cells that attack the myelin, infections that target the brain may activate an inflammatory response that then goes on to attack oligodendrocytes (16). In support of the role of inflammation on MS, IL-17 has been found to play an important role in the pathology of MS. IL-17 has been found in brain lesions of patients with MS as well as in peripheral blood mononuclear cells from these patients $(17,18)$. As a result, studies are being conducted to target IL-17 with neutralizing antibodies (19).

Multiple sclerosis remains the most common neurological disability in young adults (20). The pathological manifestations of MS include inflammation, demyelination-neurodegeneration, axonal damage, remyelination-repair, and gliosis (20). A better understanding of the molecular mechanisms contributing to these factors represents an opportunity to develop personalized therapies. From the understanding of these molecular mechanisms, one can identify potential biomarkers that can be used to guide the diagnosis, prognosis, and treatment of MS patients.

Importantly, many publications on the field of biomarker research lack adequate measures to determine the likelihood of elevated proteins in diseased cohorts as biomarkers of a particular disease. AUC values are important in biomarker analysis for this value does not change with the prevalence of a given outcome within the cohort used for that study. Moreover, it plots the sensitivity 
TABLE 2 | Receiver operator characteristic analysis results for inflammasome signaling proteins in serum and cut-off point analyses for inflammasome signaling proteins in serum.

\begin{tabular}{|c|c|c|c|c|c|}
\hline Biomarker & Area & SE & $95 \% \mathrm{Cl}$ & $P$ value & \\
\hline Caspase-1 & 0.848 & 0.07394 & 0.703-0.9929 & 0.0034 & \\
\hline $\begin{array}{l}\text { Apoptosis-associated speck-like protein } \\
\text { containing a caspase recruitment domain (ASC) }\end{array}$ & 0.9448 & 0.02122 & $0.9032-0.9864$ & $<0.0001$ & \\
\hline IL-1 beta & 0.7619 & 0.0925 & $0.5806-0.9432$ & 0.0318 & \\
\hline IL-18 & 0.7075 & 0.05216 & $0.6052-0.8097$ & 0.0003 & \\
\hline Biomarker & Cut-off point (pg/ml) & Sensitivity (\%) & Specificity (\%) & PPV (\%) & NPV (\%) \\
\hline Caspase-1 & $>1.302$ & 89 & 56 & 81 & 71 \\
\hline ASC & $>352.4$ & 84 & 90 & 70 & 95 \\
\hline IL-1 beta & $<0.825$ & 100 & 62 & 50 & 100 \\
\hline IL-18 & $>190.1$ & 84 & 44 & 29 & 91 \\
\hline
\end{tabular}

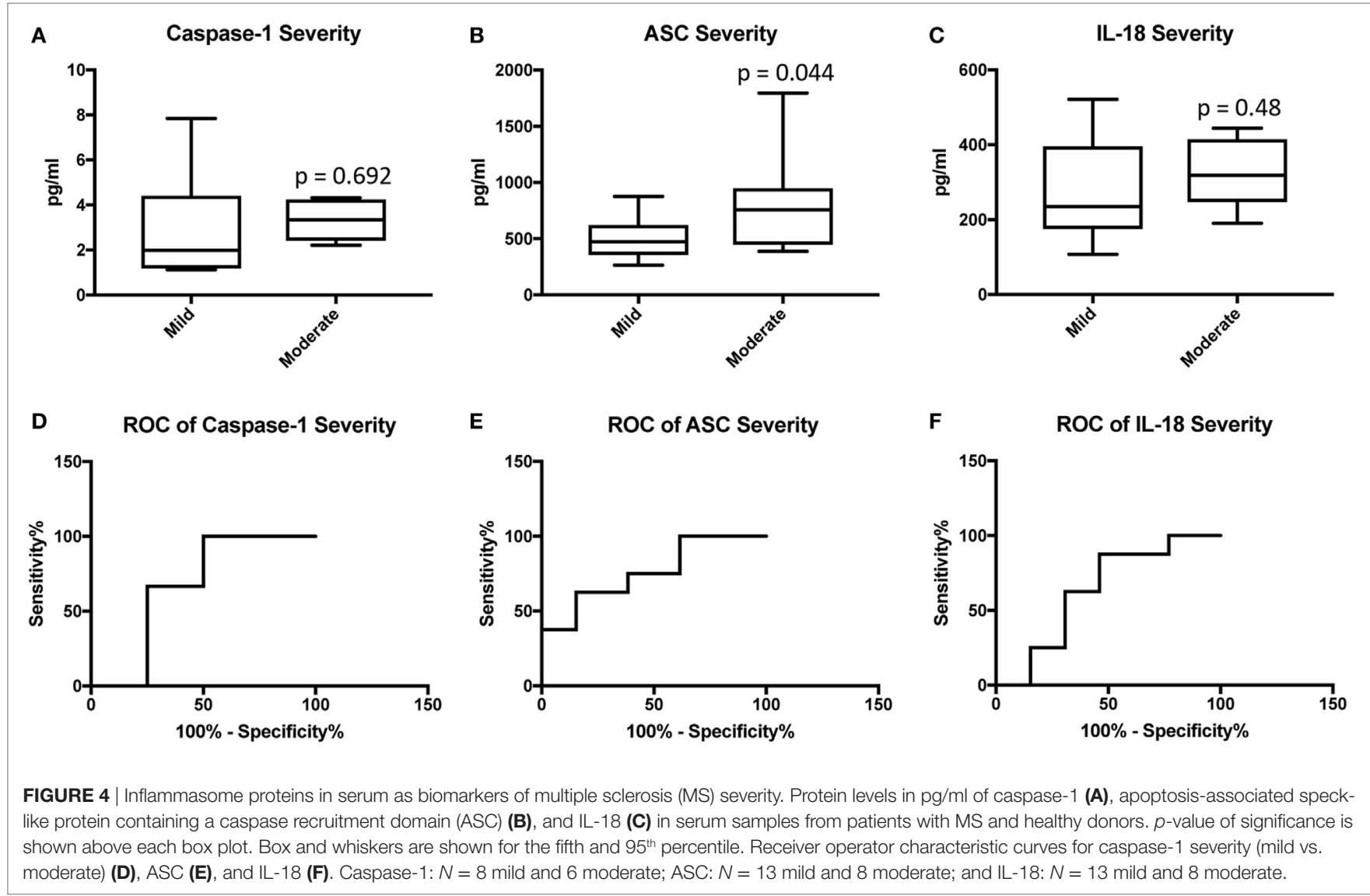

TABLE 3 | Receiver operator characteristic analysis results for inflammasome signaling proteins in serum and cut-off point analyses for inflammasome signaling proteins in serum as markers of multiple sclerosis severity (mild vs. moderate).

\begin{tabular}{|c|c|c|c|c|c|}
\hline Biomarker & Area & SE & $95 \% \mathrm{Cl}$ & $P$ value & \\
\hline Caspase-1 & 0.6667 & 0.155 & 0.3629-0.9704 & 0.30 & \\
\hline ASC & 0.7596 & 0.11 & $0.5437-0.9756$ & 0.05 & \\
\hline IL-18 & 0.6346 & 0.12 & $0.3925-0.8767$ & 0.31 & \\
\hline Biomarker & $\begin{array}{l}\text { Cut-off point } \\
(\mathrm{pg} / \mathrm{ml})\end{array}$ & $\begin{array}{c}\text { Sensitivity } \\
(\%)\end{array}$ & $\begin{array}{c}\text { Specificity } \\
(\%)\end{array}$ & $\begin{array}{l}\text { PPV } \\
\text { (\%) }\end{array}$ & $\begin{array}{r}\text { NPV } \\
(\%)\end{array}$ \\
\hline Caspase-1 & $>1.776$ & 100 & 50 & 73 & 100 \\
\hline ASC & $>537.5$ & 75 & 62 & 76 & 60 \\
\hline IL-18 & $>238.2$ & 88 & 54 & 75 & 73 \\
\hline
\end{tabular}

and specificity across the range of biomarker concentrations (21). In this study, in accordance with standards of biomarker analyses, we provide AUC values with confidence intervals, sensitivities, and specificities to identify the inflammasome proteins caspase-1, ASC, IL-1 $\beta$, and IL-18 as suitable biomarkers that can be used in the care of patients with MS. A perfect AUC value is 1.0, where $100 \%$ of subjects in the population will be correctly classified as having MS or not. In contrast, an AUC of 0.5 signifies that subjects are randomly classified as either positive or negative for MS, which has no clinical utility. It has been suggested that an AUC between 0.9 and 1.0 applies to an excellent biomarker; from 0.8 to 0.9 , good; 0.7 to 0.8 , fair; 0.6 to 0.7 , poor; and 0.5 to 0.6 , fail (21). 
The initial manifestation of demyelination is referred to as clinically isolated syndrome (CIS). Following CIS is the clinical manifestation of MS, which is referred to as clinically definite MS (CDMS) (22). The International Advisory Committee on Clinical Trials in MS describes MS with terms, such as progressing, not progressing, active, or not active as well as RRMS, and progressive MS. Progressive MS is then subdivided into primary progressive MS (PPMS) or SPMS (23). Patients with RRMS present new or recurrent symptoms with lack of disease progression between relapses. Patients with PPMS have no prior history of RRMS and present a loss of neurological function with occasional temporary minor improvements. SPMS is used to denote patients with RRMS who are progressing (24). As a result, due to the different manifestations of the disease, there is a need to find objective biomarkers that can stratify the different clinical scenarios that MS patients present.

Pharmacogenomic biomarkers (DNA, RNA) offer great potential in the care of MS patients. Recently, several genes have been identified to be associated with the response to IFN $\beta$ treatment in MS patients, including genes encoding for type I IFN and IFN regulatory transcription factors $(25,26)$. In addition, other genes have been associated with a lack of response to IFN $\beta$ treatment (27). However, future studies are needed to corroborate these findings (28). As a result, to date, magnetic resonance imaging (MRI) remains the main tool used in the diagnosis and monitoring of treatment in this patient population. MRI can image the changes in the blood-brain barrier associated with inflammatory demyelination. Moreover, using the most recent criteria allows for accurate diagnosis of MS with just one scan (29). Similarly, MRI offers strong predictability on the effect of therapy on the rate of relapse (30).

The NLRP3 inflammasome plays a major role in the pathology of MS (12). Interestingly, IFN- $\beta$ which is used as therapy in MS, acts as an inhibitor of NLRP3 inflammasome activation in the EAE model $(31,32)$. In addition, in the EAE model the pyrin inflammasome has been shown to be responsible for the production of IL-1 $\beta$ by hematopoietic cells following stimulation with pertussis toxin (14).

In humans, higher levels of IL-18 have been previously detected in the serum and cerebrospinal fluid of patients with MS $(33,34)$. In this study, we detected a statistically significant higher level of IL-18 in the serum of MS patients when compared to healthy subjects, consistent with a high AUC (0.7075).

In the EAE animal model of MS, IL- $1 \beta$ plays a major role in this demyelinating disease (35). However, in humans conflicting data exists regarding the levels of IL-1 $\beta$ in MS patients. Accordingly, some studies indicate that IL- $1 \beta$ is elevated in the serum and CSF of patients with MS. In this cohort, patients with RRMS were considered clinically active $(36,37)$; however, other studies failed to detect IL-1 $\beta$ in the body fluids of patients with MS $(38,39)$. In this study, the levels of IL- $1 \beta$ were significantly lower in the MS group than in the control group.

In humans, caspase- 1 is present in MS plaques and is elevated in peripheral blood mononuclear cells $(8,40)$. In this study, we found higher protein levels of caspase-1 in the serum of MS patients consistent with a high AUC for caspase-1 (0.848). ASC is a promising therapeutic target for CNS inflammation $(6,7,41,42)$.
In the EAE model of MS, ASC plays a critical role in disease exacerbation together with caspase-1 (43). In our analysis, ASC was the most promising biomarker with an AUC of 0.9448 .

Thus, based on these findings caspase-1 and ASC are promising biomarker with a high AUC value and a high sensitivity. Importantly, we believe that a combination of caspase-1 and ASC as biomarkers for MS with other diagnostic criteria has the potential to increase the sensitivity of these biomarkers for MS beyond what we describe here. In addition, our findings suggest that ASC could potentially be used as a diagnostic biomarker of disease severity, since we found higher levels of ASC in the moderate MS group when compared to the mild MS group, in addition to an AUC of 0.7596 .

Some clinically used biomarkers, such as serum aquaporin four antibodies (AQP4-IgG), which are used to differentiate between patients with MS and patients with neuromyelitis optica, have a median sensitivity of $62.3 \%$ with a range between 12.5 and $100 \%$, depending on the assay used for the measurements (44).

Since the 1960s immunoglobulin (Ig) G oligoclonal bands (OCB) have been used as a classic biomarker in the diagnosis of MS (45). However, the specificity of IgG-OCB is only $61 \%$, as a result, other diagnostic criteria is needed to clinically determine the diagnosis of MS (46), yet CSF-restricted IgG-OCB is a good predictor for conversion from CIS to CDMS, independently of MRI (47). Similar results have been obtained when analyzing IgM-OCB (48). Interestingly, IgG against measles, rubella, and varicella zoster (MRZ) are present in the CSF of MS patients, thus MRZ-specific IgG have the potential to be used as biomarkers of MS diagnosis (49). Similarly, when interpreting the results of this study, it is possible that the effects seen in these proteins is more related to an activation of the innate immune response rather than being MS-specific, especially for all other proteins, but ASC, which has a $90 \%$ specificity in this cohort of samples.

This study was carried in accordance with the standards for reporting diagnostic accuracy studies (STARD). Based on the STARD standards, the study presents certain limitations. For instance, serum used in this study was obtained from a bank of samples from MS patients. Thus, when samples were initially collected, the study of inflammasome signaling proteins was not envisioned. As a result, data collection was planned after collection of samples, and eligibility criteria did not consider the role of inflammation in this patient population. This has resulted in the diverse patient population used in this study. Therefore, a more controlled study-design is needed in the future to extend the results of the present study. In addition, most of the samples used in this study came from Caucasian patients. In future studies, we need to look at samples from other races, including Hispanics and patients of African descent. Moreover, some patients in this study were being treated for other conditions; as a result, it is possible that some of the effects on inflammasome protein expression in serum are not related to MS pathology, but to the other indications that patients presented, such as hypertension or hypercholesterolemia, among others.

It is important to highlight that samples used in this study came from patients that were treated for MS with drugs, such as Tysabri, which targets integrin receptors (50). The fact that 
we were able to detect higher levels of inflammasome proteins despite treatment, suggests that there is still a need for drugs to target the inflammasome and other components of the immune response as therapies for MS. Moreover, another limitation of this study is that only 3 of the 32 samples belong to patients that were not receiving any treatment for MS at the time of collection. Therefore, future studies should look at these proteins in serum samples from treatment-naïve MS patients.

In addition, future research is needed to better determine the prognostic potential of these inflammasome markers on the pathology of MS. In addition, more studies are needed looking at larger patient populations to better determine the cut-off points that will give the higher specificity and sensitivity to each biomarker as a diagnostic tool of MS disease. There is also a need to look at the different levels of inflammasome proteins in the different types of MS patients as well as in patients receiving different therapies. Importantly, in this study we have identified caspase- 1 and ASC as potential biomarkers of MS pathology with high AUC values; 0.9448 and 0.848 , respectively with sensitivities above $80 \%$ and in the case of ASC a specificity of $90 \%$.

\section{REFERENCES}

1. Compston A. The pathogenesis and basis for treatment in multiple sclerosis. Clin Neurol Neurosurg (2004) 106:246-8. doi:10.1016/j.clineuro. 2004.02.007

2. Hohlfeld R, Wekerle H. Autoimmune concepts of multiple sclerosis as a basis for selective immunotherapy: from pipe dreams to (therapeutic) pipelines. Proc Natl Acad Sci U S A (2004) 101(Suppl 2):14599-606. doi:10.1073/ pnas.0404874101

3. Cossburn MD, Harding $\mathrm{K}$, Ingram $\mathrm{G}$, El-Shanawany $\mathrm{T}$, Heaps $\mathrm{A}$, Pickersgill TP, et al. Clinical relevance of differential lymphocyte recovery after alemtuzumab therapy for multiple sclerosis. Neurology (2013) 80:55-61. doi:10.1212/WNL.0b013e31827b5927

4. Frau J, Coghe G, Fenu G, Lorefice L, Cocco E. Rescue therapy with alemtuzumab in multiple sclerosis post-natalizumab puerperium reactivation. Neurol Sci (2017) 39(2):389-90. doi:10.1007/s10072-017-3135-y

5. Steinman L. Induction of new autoimmune diseases after alemtuzumab therapy for multiple sclerosis: learning from adversity. JAMA Neurol (2017) 74:907-8. doi:10.1001/jamaneurol.2017.0325

6. de Rivero Vaccari JP, Lotocki G, Marcillo AE, Dietrich WD, Keane RW. A molecular platform in neurons regulates inflammation after spinal cord injury. J Neurosci (2008) 28:3404-14. doi:10.1523/JNEUROSCI.015708.2008

7. AdamczakSE, DeRivero VaccariJP,Dale G, BrandFJIII, Nonner D, BullockMR, et al. Pyroptotic neuronal cell death mediated by the AIM2 inflammasome. J Cereb Blood Flow Metab (2014) 34:621-9. doi:10.1038/jcbfm.2013.236

8. Ming X, Li W, Maeda Y, Blumberg B, Raval S, Cook SD, et al. Caspase-1 expression in multiple sclerosis plaques and cultured glial cells. J Neurol Sci (2002) 197:9-18. doi:10.1016/S0022-510X(02)00030-8

9. Cao Y, Goods BA, Raddassi K, Nepom GT, Kwok WW, Love JC, et al. Functional inflammatory profiles distinguish myelin-reactive $\mathrm{T}$ cells from patients with multiple sclerosis. Sci Transl Med(2015) 7:287ra274. doi:10.1126/ scitranslmed.aaa8038

10. Furlan R, Martino G, Galbiati F, Poliani PL, Smiroldo S, Bergami A, et al. Caspase-1 regulates the inflammatory process leading to autoimmune demyelination. J Immunol (1999) 163:2403-9.

11. Gris D, Ye Z, Iocca HA, Wen H, Craven RR, Gris P, et al. NLRP3 plays a critical role in the development of experimental autoimmune encephalomyelitis by mediating Th1 and Th17 responses. J Immunol (2010) 185:974-81. doi:10.4049/jimmunol.0904145

12. Inoue M, Williams KL, Gunn MD, Shinohara ML. NLRP3 inflammasome induces chemotactic immune cell migration to the CNS in experimental

\section{ETHICS STATEMENT}

Subjects were enrolled in the study Prospective Collection of Samples for Research according to IRB \# 201301461 approved by Schulman Associates IRB for BioreclamationIVT. Samples used in this study were purchased from BioreclamationIVT.

\section{AUTHOR CONTRIBUTIONS}

JV contributed to the design of the experiments, he ran the experiments, performed data analyses, and wrote the manuscript. RK contributed to the design of the experiments, performed data analyses, and wrote the manuscript. WD contributed to the design of the experiments, performed data analyses, and wrote the manuscript.

\section{FUNDING}

This work was supported by a STTR grant (NS086274) from the NINDS/NIH to RK and WD.

autoimmune encephalomyelitis. Proc Natl Acad Sci U S A (2012) 109:10480-5. doi:10.1073/pnas.1201836109

13. Brand FJ III, Forouzandeh M, Kaur H, Travascio F, De Rivero Vaccari JP. Acidification changes affect the inflammasome in human nucleus pulposus cells. J Inflamm (Lond) (2016) 13:29. doi:10.1186/s12950-016-0137-0

14. Dumas A, Amiable N, De Rivero Vaccari JP, Chae JJ, Keane RW, Lacroix S, et al. The inflammasome pyrin contributes to pertussis toxin-induced IL-1beta synthesis, neutrophil intravascular crawling and autoimmune encephalomyelitis. PLoS Pathog (2014) 10:e1004150. doi:10.1371/journal.ppat. 1004150

15. Dendrou CA, Fugger L, Friese MA. Immunopathology of multiple sclerosis. Nat Rev Immunol (2015) 15:545-58. doi:10.1038/nri3871

16. Trapp BD, Nave KA. Multiple sclerosis: an immune or neurodegenerative disorder? Annu Rev Neurosci (2008) 31:247-69. doi:10.1146/annurev. neuro.30.051606.094313

17. Matusevicius D, Kivisakk P, He B, Kostulas N, Ozenci V, Fredrikson S, et al. Interleukin-17 mRNA expression in blood and CSF mononuclear cells is augmented in multiple sclerosis. Mult Scler (1999) 5:101-4. doi:10.1177/ 135245859900500206

18. Lock C, Hermans G, Pedotti R, Brendolan A, Schadt E, Garren H, et al. Gene-microarray analysis of multiple sclerosis lesions yields new targets validated in autoimmune encephalomyelitis. Nat Med (2002) 8:500-8. doi:10.1038/nm0502-500

19. Havrdova E, Belova A, Goloborodko A, Tisserant A, Wright A, Wallstroem E, et al. Activity of secukinumab, an anti-IL-17A antibody, on brain lesions in RRMS: results from a randomized, proof-of-concept study. J Neurol (2016) 263:1287-95. doi:10.1007/s00415-016-8128-x

20. Katsavos S, Anagnostouli M. Biomarkers in multiple sclerosis: an up-to-date overview. Mult Scler Int (2013) 2013:340508. doi:10.1155/2013/340508

21. Xia J, Broadhurst DI, Wilson M, Wishart DS. Translational biomarker discovery in clinical metabolomics: an introductory tutorial. Metabolomics (2013) 9:280-99. doi:10.1007/s11306-012-0482-9

22. KuhleJ, Disanto G, Dobson R, Adiutori R, Bianchi L, Topping J, et al. Conversion from clinically isolated syndrome to multiple sclerosis: a large multicentre study. Mult Scler (2015) 21:1013-24. doi:10.1177/1352458514568827

23. Lublin FD. New multiple sclerosis phenotypic classification. Eur Neurol (2014) 72(Suppl 1):1-5. doi:10.1159/000367614

24. Milo R, Miller A. Revised diagnostic criteria of multiple sclerosis. Autoimmun Rev (2014) 13:518-24. doi:10.1016/j.autrev.2014.01.012

25. Cunningham S, Graham C, Hutchinson M, Droogan A, O'rourke K, Patterson C, et al. Pharmacogenomics of responsiveness to interferon IFN-beta treatment in multiple sclerosis: a genetic screen of 100 type 
I interferon-inducible genes. Clin Pharmacol Ther (2005) 78:635-46. doi:10.1016/j.clpt.2005.08.018

26. Coyle PK. Pharmacogenetic biomarkers to predict treatment response in multiple sclerosis: current and future perspectives. Mult Scler Int (2017) 2017:6198530. doi:10.1155/2017/6198530

27. Tsareva E, Kulakova O, Boyko A, Favorova O. Pharmacogenetics of multiple sclerosis: personalized therapy with immunomodulatory drugs. Pharmacogenet Genomics (2016) 26:103-15. doi:10.1097/FPC.0000000000000194

28. Martire S, Navone ND, Montarolo F, Perga S, Bertolotto A. A gene expression study denies the ability of 25 candidate biomarkers to predict the interferon-beta treatment response in multiple sclerosis patients. J Neuroimmunol (2016) 292:34-9. doi:10.1016/j.jneuroim.2016.01.010

29. Thompson AJ, Banwell BL, Barkhof F, Carroll WM, Coetzee T, Comi G, et al. Diagnosis of multiple sclerosis: 2017 revisions of the McDonald criteria. Lancet Neurol (2017) 17(2):162-73. doi:10.1016/S1474-4422(17)30470-2

30. Sormani MP, Bruzzi P. MRI lesions as a surrogate for relapses in multiple sclerosis: a meta-analysis of randomised trials. Lancet Neurol (2013) 12:669-76. doi:10.1016/S1474-4422(13)70103-0

31. Inoue M, Williams KL, Oliver T, Vandenabeele P, Rajan JV, Miao EA, et al. Interferon-beta therapy against EAE is effective only when development of the disease depends on the NLRP3 inflammasome. Sci Signal (2012) 5:ra38. doi:10.1126/scisignal.2002767

32. Inoue M, Chen PH, Siecinski S, Li QJ, Liu C, Steinman L, et al. An interferon-beta-resistant and NLRP3 inflammasome-independent subtype of EAE with neuronal damage. Nat Neurosci (2016) 19:1599-609. doi:10.1038/ nn. 4421

33. Losy J, Niezgoda A. IL-18 in patients with multiple sclerosis. Acta Neurol Scand (2001) 104:171-3. doi:10.1034/j.1600-0404.2001.00356.x

34. Chen YC, Chen SD, Miao L, Liu ZG, Li W, Zhao ZX, et al. Serum levels of interleukin (IL)-18, IL-23 and IL-17 in Chinese patients with multiple sclerosis. J Neuroimmunol (2012) 243:56-60. doi:10.1016/j.jneuroim.2011.12.008

35. Levesque SA, Pare A, Mailhot B, Bellver-Landete V, Kebir H, Lecuyer MA, et al. Myeloid cell transmigration across the CNS vasculature triggers IL-1beta-driven neuroinflammation during autoimmune encephalomyelitis in mice. J Exp Med (2016) 213:929-49. doi:10.1084/jem.20151437

36. Hauser SL, Doolittle TH, Lincoln R, Brown RH, Dinarello CA. Cytokine accumulations in CSF of multiple sclerosis patients: frequent detection of interleukin-1 and tumor necrosis factor but not interleukin-6. Neurology (1990) 40:1735-9. doi:10.1212/WNL.40.11.1735

37. Dujmovic I, Mangano K, Pekmezovic T, Quattrocchi C, Mesaros S, Stojsavljevic N, et al. The analysis of IL-1 beta and its naturally occurring inhibitors in multiple sclerosis: the elevation of IL-1 receptor antagonist and IL-1 receptor type II after steroid therapy. J Neuroimmunol (2009) 207:101-6. doi:10.1016/j.jneuroim.2008.11.004

38. Maimone D, Gregory S, Arnason BG, Reder AT. Cytokine levels in the cerebrospinal fluid and serum of patients with multiple sclerosis. J Neuroimmunol (1991) 32:67-74. doi:10.1016/0165-5728(91)90073-G

39. Tsukada N, Miyagi K, Matsuda M, Yanagisawa N, Yone K. Tumor necrosis factor and interleukin- 1 in the CSF and sera of patients with multiple sclerosis. J Neurol Sci (1991) 104:230-4. doi:10.1016/0022-510X(91)90315-X
40. Huang WX, Huang P, Hillert J. Increased expression of caspase-1 and interleukin-18 in peripheral blood mononuclear cells in patients with multiple sclerosis. Mult Scler (2004) 10:482-7. doi:10.1191/1352458504ms1071oa

41. de Rivero Vaccari JP, Lotocki G, Alonso OF, Bramlett HM, Dietrich WD, Keane RW. Therapeutic neutralization of the NLRP1 inflammasome reduces the innate immune response and improves histopathology after traumatic brain injury. JCereb Blood Flow Metab (2009) 29:1251-61. doi:10.1038/ jcbfm.2009.46

42. de Rivero Vaccari JP, Dietrich WD, Keane RW. Therapeutics targeting the inflammasome after central nervous system injury. Transl Res (2016) 167: 35-45. doi:10.1016/j.trsl.2015.05.003

43. Shaw PJ, Lukens JR, Burns S, Chi H, Mcgargill MA, Kanneganti TD. Cutting edge: critical role for PYCARD/ASC in the development of experimental autoimmune encephalomyelitis. J Immunol (2010) 184:4610-4. doi:10.4049/ jimmunol.1000217

44. Jarius S, Wildemann B. Aquaporin-4 antibodies (NMO-IgG) as a serological marker of neuromyelitis optica: a critical review of the literature. Brain Pathol (2013) 23:661-83. doi:10.1111/bpa.12084

45. Stangel M, Fredrikson S, Meinl E, Petzold A, Stuve O, Tumani H. The utility of cerebrospinal fluid analysis in patients with multiple sclerosis. Nat Rev Neurol (2013) 9:267-76. doi:10.1038/nrneurol.2013.41

46. Teunissen CE, Malekzadeh A, Leurs C, Bridel C, Killestein J. Body fluid biomarkers for multiple sclerosis - the long road to clinical application. Nat Rev Neurol (2015) 11:585-96. doi:10.1038/nrneurol.2015.173

47. Tintore M, Rovira A, Rio J, Tur C, Pelayo R, Nos C, et al. Do oligoclonal bands add information to MRI in first attacks of multiple sclerosis? Neurology (2008) 70:1079-83. doi:10.1212/01.wnl.0000280576.73609.c6

48. Villar LM, Masjuan J, Gonzalez-Porque P, Plaza J, Sadaba MC, Roldan E, et al. Intrathecal IgM synthesis predicts the onset of new relapses and a worse disease course in MS. Neurology (2002) 59:555-9. doi:10.1212/WNL. 59.4 .555

49. Brettschneider J, Tumani H, Kiechle U, Muche R, Richards G, Lehmensiek V, et al. IgG antibodies against measles, rubella, and varicella zoster virus predict conversion to multiple sclerosis in clinically isolated syndrome. PLoS One (2009) 4:e7638. doi:10.1371/journal.pone.0007638

50. Selewski DT, Shah GV, Segal BM, Rajdev PA, Mukherji SK. Natalizumab (Tysabri). AJNR Am J Neuroradiol (2010) 31:1588-90. doi:10.3174/ajnr. A2226

Conflict of Interest Statement: JV, RK, and WD are co-founders and managing members of InflamaCORE, LLC, and have patents on inflammasome proteins as biomarkers of injury and disease as well as on targeting inflammasome proteins for therapeutic purposes.

Copyright (๑) 2018 Keane, Dietrich and de Rivero Vaccari. This is an open-access article distributed under the terms of the Creative Commons Attribution License (CC BY). The use, distribution or reproduction in other forums is permitted, provided the original author(s) and the copyright owner are credited and that the original publication in this journal is cited, in accordance with accepted academic practice. No use, distribution or reproduction is permitted which does not comply with these terms. 